\title{
Cathode-supported hybrid direct carbon fuel cells
}

Vanesa Gil*, Jonas Gurauskis ${ }^{1}$, Lisa Deleebeeck ${ }^{2}$, Eugen Stamate, K. Kammer Hansen

Department of Energy Conversion and Storage, Technical University of Denmark, DK-4000

Roskilde, Denmark

\begin{abstract}
The direct conversion of coal to heat and electricity by a hybrid direct carbon fuel cell (HDCFC) is a highly efficient and cleaner technology than the conventional combustion power plants. HDCFC is defined as a combination of solid oxide fuel cell and molten carbonate fuel cell. This work investigates cathode-supported cells as an alternative configuration for HDCFC, with better catalytic activity and performance. This study aims to define the best processing route to manufacture highly efficient cathode-supported cells based on $\mathrm{La}_{0.75} \mathrm{Sr}_{0.25} \mathrm{MnO}_{3} /$ yttria-stabilized zirconia infiltrated backbones. The challenges on the development of high-performance backbones are discussed. In this study, cathode supported configuration was confirmed to be more efficient for the oxidation of carbon than anode supported configuration. The maximum power density of the cathode-supported cell increased almost by a factor of two when compared with the anodesupported cell.
\end{abstract}

Keywords: Direct carbon fuel cells; Cathode-supported, Solid oxide fuel cell, Backbone

\section{Introduction}

Hybrid direct carbon fuel cells (HDCFCs) are of interest as they represent a highly efficient method of the oxidation (without combustion) of solid carbon for the generation of electricity (100\% theoretical efficiency). This technology also promises to result in the emission of virtually no $\mathrm{NO}_{\mathrm{x}}$, due to no direct contact between the $\mathrm{N}_{2}$ in air and fuel, a reduction in production of other air pollutants (e.g., $\mathrm{SO}_{\mathrm{x}}$, particulates), and to provide a very high purity stream of $\mathrm{CO}_{2}$ for capture and storage [1].

The HDCFC concept consists of a solid oxide fuel cell (SOFC) cathode and electrolyte and a molten alkali carbonate-solid carbon slurry in the anode chamber [2]. In this design the presence of melted carbonates at operating temperature in the carbon fuel helps both to strongly increase the

*Corresponding author: V. Gil. Tel.: +45 29637307. E-mail address: gilh@dtu.dk.

${ }^{1}$ Present address: Æneam IVS, 2450 København, E-mail address: jonasg@aeneam.com.

${ }^{2}$ Present address: Danish Fundamental Metrology, 2800 Kgs. Lyngby, E-mail address: lisa.deleebeeck@gmail.com. 
contact between the solid carbon and the solid oxide electrode and to extend the electrolyte into the solid carbon.

The HDCFC solution allows the use of current SOFC cells usually fed with hydrogen. Typically, HDCFCs have been investigated as anode or electrolyte-supported configurations [3-6].

Anode chamber processes have been found to be limiting to full-cell HDCFCs [7], hence catalysts are sought to improve performance [8]. In addition, previous results in our group have demonstrate that the electrochemical reaction between carbonates/carbon fuel and the solid oxide electrode is limited to a few microns in the outer layer of the anode, strongly limiting the cell performance. The finding of a new cell configuration becomes essential to increase the utilization of the entire anode reaction volume and consequently to improve the HDCFCs' performance.

Here we present a new concept; cathode-side supported planar HDCFCs, which present the advantage of the use of a thin anode layer to promote the full contact between the fuel and the solid oxide cell anode together with the use of a thin electrolyte, maintaining low ohmic resistances. Although the benefits of such cell configuration, the manufacturing of high-performance cathodesupported cells remains extremely challenging [9].

Conventional LSM/YSZ composite materials has a low sintering temperature that can lead to the loss of triple phase boundaries due to excessive coarsening of LSM and YSZ particles when cofired at the temperature required to obtain a dense electrolyte layer [10]. Recently it has been report that the use of a sintering inhibitor e.g. gadolinium-doped ceria might prevent the fast coarsening issue [11].

Another major issue is the chemical compatibility of these components during processing of the cathode-supported cell. It is reported that LSM and YSZ form insulating phases based on zirconates e.g. $\mathrm{La}_{2} \mathrm{Zr}_{2} \mathrm{O}_{7}, \mathrm{SrZrO}_{3}$ when co-firing at temperatures required to ensure the well-formed electrode/electrolyte interphase in the cathode-supported cell [12].

Additionally, avoidance of high cathodic polarization resistances due to low conductivity is a key issue in the development of cathode supported configuration cells.

Infiltrated electrodes have shown great potential to minimize the problems of low conductivity and solid-state reactions between components $[13,14]$. The approach is based on the fabrication of a highly porous ceramic backbone (YSZ or cerium-gadolinium oxide (CGO)), which is co-sintered together with the electrolyte, and then impregnated with the active components, which are subsequently calcined at lower temperatures. The separate sintering/calcination temperature for the ceramic backbone and the other components of the electrode avoid the formation of solid-state 
reaction products. Furthermore, the microstructure achieved, where the active components coat the surface of the pre-formed backbone, is advantageous comparing to composites prepared using more conventional methods [15].

The purpose of this work is to present the development of high performance infiltrated backbones as a suitable route for manufacturing cathodes for alternative cathode-supported HDCFCs. The microstructural features and electrochemical behavior are discussed in detail by comparing infiltrated backbones, where the porosity is obtained by using either pyrolyzable pore formers (graphite and poly methyl methacrylate (PMMA)) or by Ni-leaching processes. Finally, the performance, current-potential-power density (I-V-P) curves of the cathode vs. anode-supported HDCFC's with carbon black as the fuel is investigated.

\section{Material and methods}

\subsection{Cathodes fabrication}

Two backbone configurations were pursued: "Type A" where the porosity is obtained by the use of low temperature pyrolyzable pore formers (Figure 1a), and "Type B" with the porous backbone is obtained by acid leaching of Ni/YSZ substrates (Figure 1b). The powders used in the present study were $\mathrm{Y}_{0.15} \mathrm{Zr}_{0.85} \mathrm{O}_{1.95} \quad\left(8 \mathrm{~mol} \% \quad \mathrm{Y}_{2} \mathrm{O}_{3}\right.$ stabilized $\left.\mathrm{ZrO}_{2}-8 \mathrm{YSZ}\right)$ from Tosoh, Japan, and $\left(\mathrm{La}_{0.75} \mathrm{Sr}_{0.25}\right)_{0.95} \mathrm{Mn}_{1.05} \mathrm{O}_{3+\delta}$ (LSM) from Haldor Topsøe A/S, Denmark. Graphite from Alfa Aesar and PMMA from Esprix technologies were used as pore formers.

Layers of NiO/YSZ (45 wt.\% NiO - 55 wt.\% YSZ), LSM/YSZ (48 wt.\% LSM - 52 wt.\% YSZ) and dense YSZ as electrolyte or porous YSZ as backbone were produced by tape casting. Details on the tape manufacturing processes are described in previous works [16, 17].

The green tape cast layers were laminated, punched and co-sintered in air at $1250{ }^{\circ} \mathrm{C}$ for $5 \mathrm{~h}$ ("Type A") and $1300{ }^{\circ} \mathrm{C}$ for $5 \mathrm{~h}$ (“Type B"). After sintering, “Type B" half cells were reduced in $\mathrm{H}_{2}$ at 800 ${ }^{\circ} \mathrm{C}$ for $3 \mathrm{~h}$ in a 10 vol\% $\mathrm{H}_{2}-\mathrm{Ar}$ atmosphere to convert the $\mathrm{NiO}$ to $\mathrm{Ni}$. Afterwards, $\mathrm{Ni}$ was removed from the cermet by acid leaching [18] resulting in highly porous YSZ backbones.

An aqueous $3 \mathrm{M}$ concentration $\mathrm{La}_{0.75} \mathrm{Sr}_{0.25} \mathrm{Mn}_{1.05} \mathrm{O}_{3+\delta}(\mathrm{LSM} 25)$ solution containing the metal nitrates in the appropriate ratio and the surfactant Pluoronic ${ }^{\odot} \mathrm{P} 123$ (BASF Cooperation) $\left(0.6 \mathrm{mg} \mathrm{mL}^{-1}\right)$ was used for sintered backbone structure/support infiltration. The following precursors were used to obtain this solution: $\mathrm{La}\left(\mathrm{NO}_{3}\right)_{3} \cdot 6 \mathrm{H}_{2} \mathrm{O}$ (Alfa Aesar, 99.9\%), $\mathrm{Sr}\left(\mathrm{NO}_{3}\right)_{2}$ (Sigma Aldrich, 99\%), and $\mathrm{Mn}\left(\mathrm{NO}_{3}\right)_{2} \cdot 4 \mathrm{H}_{2} \mathrm{O}$ (Alfa Aesar, 98\%). The infiltration was done by submerging the samples into the precursor solution and applying vacuum ( 15 mbar) in a vacuum chamber (Citovac, Struers, 
Germany). To reduce the viscosity of the highly concentrated precursor solution and enhance the impregnation of the liquid into the porous structure, the solution was warmed up to $60{ }^{\circ} \mathrm{C}$ prior to infiltration procedure. The infiltrations were repeated 4 times to obtain a LSM loading of ca. 15-20 vol\%, which was estimated by taking into consideration the sample weights before and after each infiltration step, thicknesses of infiltrated layers, theoretical densities for the backbones and material impregnated and dimensions of the samples. Following each infiltration the nitrate was decomposed to oxide at $450{ }^{\circ} \mathrm{C}$ for $15 \mathrm{~min}$.
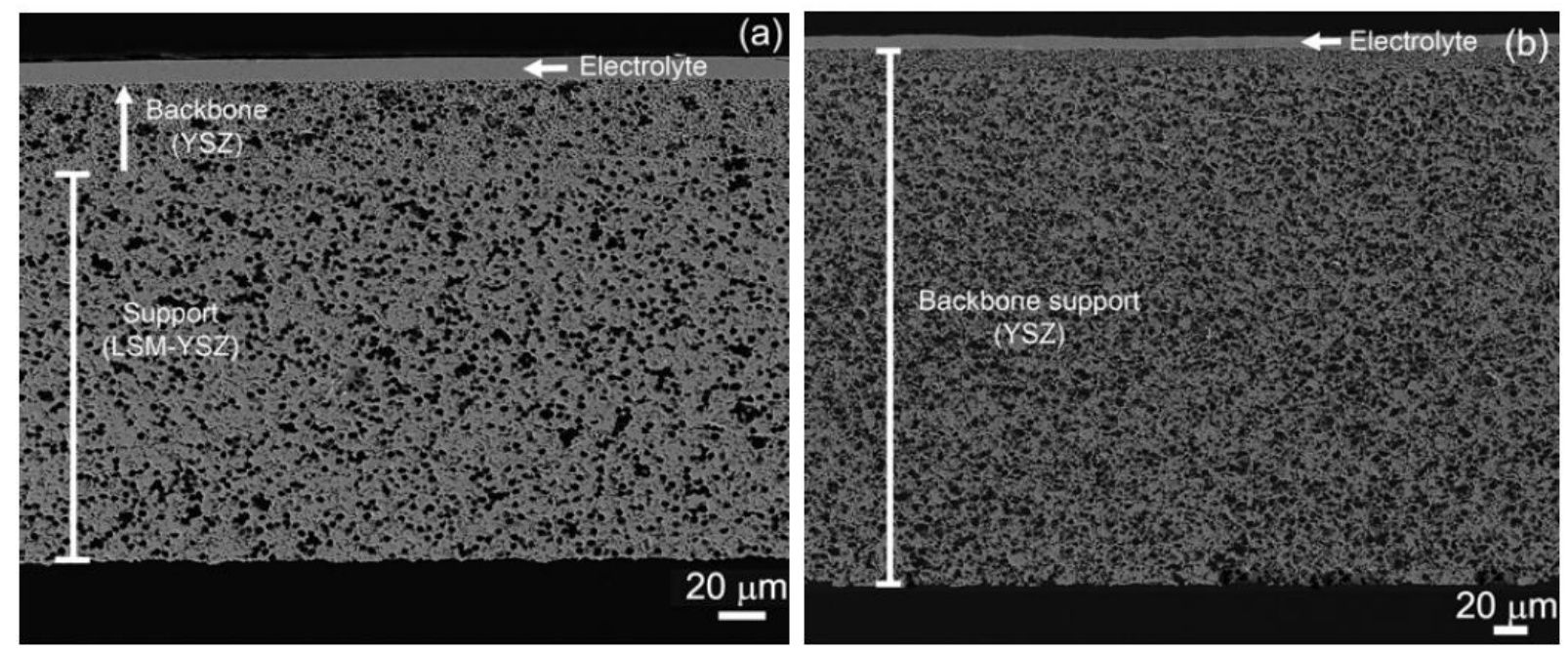

Figure 1. Sketch of the cathode-supported half cells, (a) "Type A" based on the use of sacrificial pore formers, and (b) "Type B" with backbone obtained by acid leaching.

\subsection{Characterization}

The porosity and pore size distribution of the backbones/supports, before LSM infiltration, were determined by mercury intrusion porosimetry (Autopore IV 9500V1.05 from Micrometrics Instrument Corporation, Norcross, GA).

The gas permeability coefficient $\mathrm{K}\left(\mathrm{m}^{2} \cdot \mathrm{s}^{-1}\right)$ [19] of sintered supports before and after LSM infiltration was evaluated at room temperature $\left(22^{\circ} \mathrm{C}\right)$ using disk geometry samples with a surface area of $1 \mathrm{~cm}^{2}$. The samples were mounted in such a way as to expose one side to ambient pressure, while the other side was pressurized with nitrogen. The measurements were performed by controlling the nitrogen pressure within the range of 0.5 to 2 bar and recording gas flow at the permeate side. The uncertainty in pressure of the pressurized part of the chamber and steady state gas flux (J) at permeate side were $0.02 \mathrm{bar}$ and $0.001 \mathrm{~kg} \cdot \mathrm{m}^{-2} \cdot \mathrm{s}^{-1}$, respectively. 
The formation and growth of the crystalline phases from the LSM precursor solution was followed by in-situ high temperature X-ray diffraction (HT-XRD). A Bruker D8 Advance diffractometer with $\mathrm{CuK} \alpha$ radiation and a PSD LynxEye detector equipped with a MRI high temperature stage was used. The experiment was done by dripping the solution on top of a Pt foil and heating from room temperature to $900{ }^{\circ} \mathrm{C}$, with diffraction patterns recorded every 50-100 C.

The phase compositions of the sintered backbones/supports, prior to infiltration, were also analyzed at room temperature by X-ray powder diffraction (Bruker D8 Advance diffractometer).

Scanning electron microscopy (SEM) was used for studying fractured surfaces of the half-cells, before and after LSM infiltration. The observations were carried out at a low accelerating voltage of $5 \mathrm{kV}$ with a high-resolution field emission scanning electron microscope (FESEM, Supra 35, Carl Zeiss, Germany) equipped with an energy dispersive spectroscopy (EDS) detector. The crosssection observations were made on samples vacuum embedded in Epofix (Struers, Denmark), ground and polished to $1 \mu \mathrm{m}$.

The infiltrated backbones were electrochemically characterized as cathodes and tested in a quasisymmetrical cell configuration. A standard LSM-YSZ cathode was screen-printed onto the $5 \times 5 \mathrm{~cm}^{2}$ pre-sintered $\left(1250{ }^{\circ} \mathrm{C}\right)$ half cells and afterwards sintered at $1050{ }^{\circ} \mathrm{C}$ prior to the infiltration. The performance is compared to standard LSM-YSZ screen-printed symmetrical cells sintered at 1050 ${ }^{\circ} \mathrm{C}$. The quasi-symmetric infiltrated cells and the symmetrical cells as reference were cut $4 \times 4 \mathrm{~mm}^{2}$ and gold sputtering prior to impedance test. For the electrochemical characterization, impedance spectra in the frequency range from approximately $79 \mathrm{kHz}$ to $0.1 \mathrm{~Hz}$ with a $36 \mathrm{mV}$ perturbation were collected on quasi-symmetrical cells at 700,750 and $800{ }^{\circ} \mathrm{C}$ in 20 vol. $\% \mathrm{O}_{2}$ in Ar. For the measurements a Gamry reference 600 was used.

\subsection{Cell testing}

Cathode-supported and anode-supported full-cells were setup and the fuel supplied as described in Deleebeeck et al. [8]. Briefly, the anode-supported cells consisted of a NiO-YSZ cermet anode and a YSZ electrolyte $(10 \mu \mathrm{m})$, acquired as half-cell from Topsoe Fuel Cell A/S, Denmark. A LSMYSZ cathode, and LSM current collector layer were screen-printed in-house. The cathode-supported cells consisted of Type "A" half-cells configuration with NiO-YSZ anode layer tape casted, laminated and co-sintered at $1250{ }^{\circ} \mathrm{C}$. Carbon, as carbon black acetyelene (99.9+\%, Alfa Aesar), was introduced to the anode chamber as $4: 1 \mathrm{wt} . \%$ carbon:(62-38 wt\% $\mathrm{Li}-\mathrm{K})_{2} \mathrm{CO}_{3}$. A Ni mesh was utilized as an anode current collector, while Au mesh was employed at the cathode. 
Cells were heated to $800{ }^{\circ} \mathrm{C}$ with $\mathrm{N}_{2}(5 \mathrm{~L} / \mathrm{hr})$ at the anode and air $(19 \mathrm{~L} / \mathrm{hr})$ at the cathode. Following reduction of $\mathrm{NiO}$, the performance was measured at $755^{\circ} \mathrm{C}$ with $80-20 \mathrm{vol} \% \mathrm{~N}_{2}-\mathrm{CO}_{2}$ at the anode $(5 \mathrm{~L} / \mathrm{hr}$ total flow rate). Current-voltage (I-V) curves were acquired as current was varied between OCV and $170 \mathrm{~mA} / \mathrm{cm}^{2}$. Power density and current density were calculated based on the geometric surface area of the cathode $\left(12 \mathrm{~cm}^{2}\right)$.

\section{Results and discussion}

\subsection{Porous structures characterization}

Pore size distributions of the backbones/supports before electrocatalyst infiltration were analyzed using mercury intrusion porosimetry. Figure 2 a shows that the pore size distribution for the Type "B"-backbone (porous YSZ obtained by leaching) is narrower than Type "A"-backbone (LSM-YSZ support/backbone), where the mean pore sizes were $\sim 0.7$ and $\sim 0.9 \mu \mathrm{m}$, respectively.

As Corbin and co-workers reported [20], the disadvantage related to the use of pore formers with small particle size and spherical shape (as PMMA) results in the formation of bottlenecks pores, i.e., meso pores connected to larger ones in the sub-/micro-meter range. This issue cannot be avoided unless the amount of pore former used reaches the percolation threshold.

With the mercury porosimetry technique the pore size is calculated from the pressure required to push the mercury through the sample, and, hence, the smallest diameter of the pore (bottleneck) will give the measured pore size. In our study, both mean pore sizes are in the submicronic range, which suggests the absence of bottlenecks when mixing pore formers with different shapes and particle sizes (PMMA and graphite).

In spite of the finer structure for the Type "B"-backbones, the total volume porosity increased sharply up to 57 vol.\%, as compared to 40 vol.\% for Type "A"-backbones. Both backbones, with suitable open porosities for the purpose of the combined electrocatalytic infiltration and gas access, were considered good candidates as cathode structures.

To evaluate the porous microstructure of the backbones/supports developed, gas permeation measurements at room temperature were carried out. Obtained permeability coefficient $\mathrm{K}$ values, as $a$ function of mean pressure, are shown in Figure $2 b$. The permeability of Type "B" backbones prior to infiltration were two times higher than the ones corresponding to standard YSZ/Ni cermet supports used for SOFC application. Infiltration of LSM phase to the YSZ backbone resulted in a permeability decrease by $30-40 \%$, nevertheless, the obtained values showed greater dependency on pressure corresponding to a higher contribution of viscous gas flow. In the case of Type "A" 
backbones, obtained permeability coefficient values were lower (before and after infiltration) when to compare to standard supports, and presented lower dependency on the applied pressure. This illustrates that the diffusion processes are controlling the gas transport throughout Type "A" backbones and that the achieved microstructures present very fine, poorly interconnected, tortuous porosity [21].

From mercury porosimetry and gas permeability measurements it is clear that the gas permeation through the Ni-leached supports (Type "B"), with the highest porosity content, will be far more effective than through the LSM-YSZ backbone (Type "A") supports.
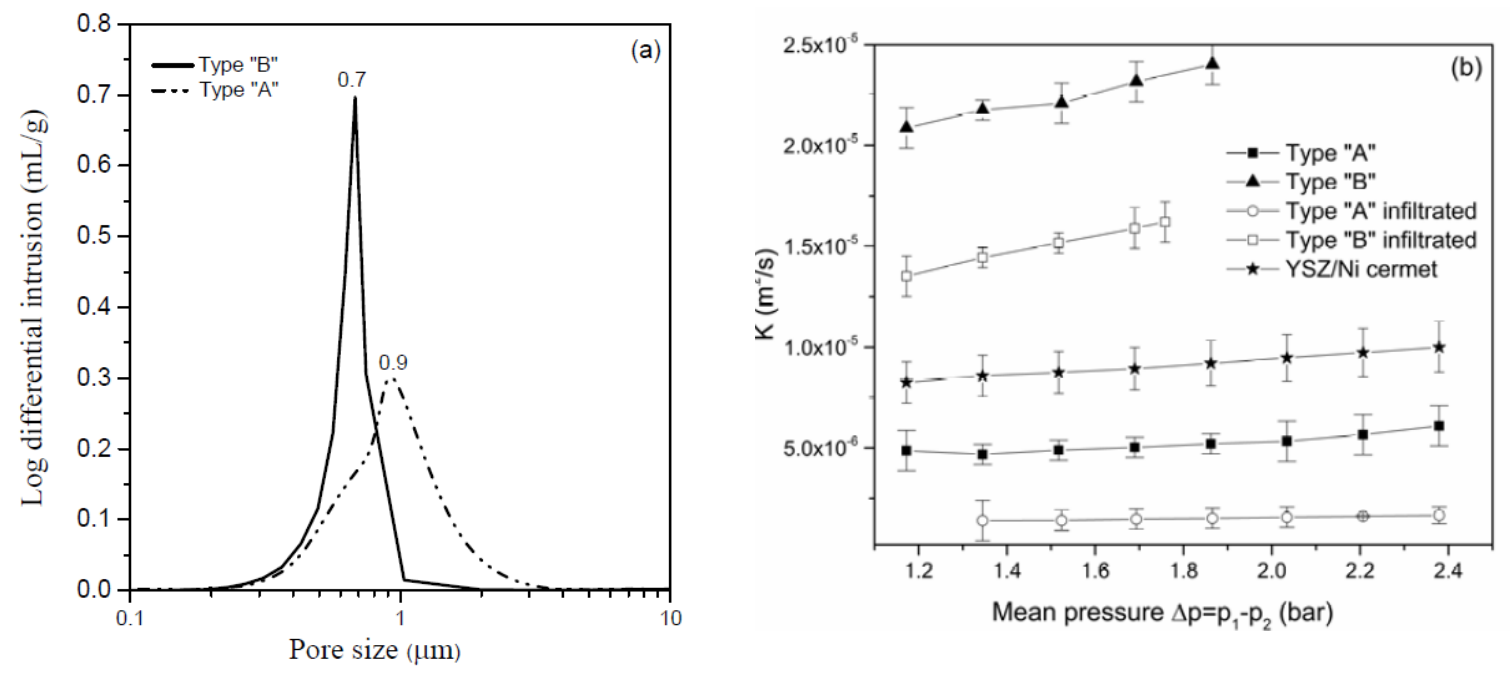

Figure 2. Evaluation of microstructural parameters of the cathode supported half cells: (a) pore size distributions measured by mercury intrusion of the backbones before infiltration and (b) permeability coefficient values as a function of mean pressure, corresponding to the backbones before and after infiltration. For comparison, standard YSZ/Ni cermet support values are given too.

No secondary phases were detected in the sintered LSM-YSZ supports (Type "A"), i.e., only those peaks corresponding to a perovskite phase (LSM) and fluorite phase (YSZ) were observed by XRD (Figure 3a). This result confirms that the processing route developed in this work is suitable for manufacture of LSM-YSZ supports, which will be used for cathode-supported HDCFCs. The XRD pattern for the YSZ backbone (Type "B") is included, only peaks corresponding to a fluorite phase (YSZ) are observed, which confirms the full removal of the nickel phase by acid leaching.

\subsection{Infiltrated backbones/support}

The temperature at which the LSM oxide phase was formed from the precursor solution was identified by in-situ high temperature X-ray diffraction (HT-XRD). The HT-XRD patterns obtained for the precursor in the temperature range of 60 to $900^{\circ} \mathrm{C}$ are shown in Figure $3 \mathrm{~b}$. 
The crystallization starts at $300{ }^{\circ} \mathrm{C}$ and the oxide phase is formed between 500 and550 ${ }^{\circ} \mathrm{C}$, where the LSM peaks start to be defined. However, it is not until above $800{ }^{\circ} \mathrm{C}$ that the precursor solution became the pursued single phase, which is confirmed by the observation of only well-defined peaks corresponding to a perovskite phase (LSM, $\left.900^{\circ} \mathrm{C}\right)$.
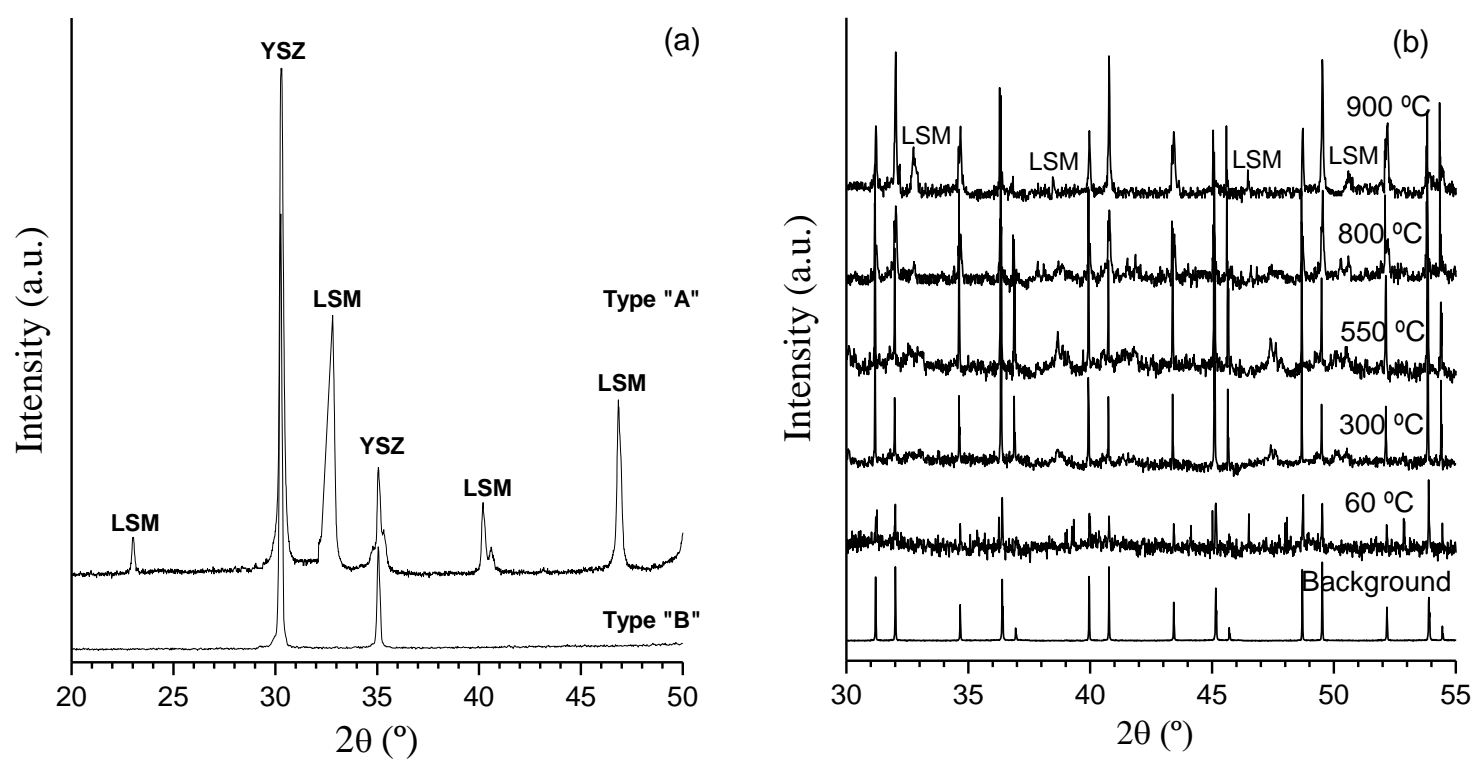

Figure 3. (a) XRD patterns of LSM-YSZ support sintered at $1250{ }^{\circ} \mathrm{C}$ for $5 \mathrm{~h}$ (Type "A") and YSZ backbone obtained by acid leaching (Type "B"). (b) In-situ high temperature XRD patterns of the LSM precursor solution after heating at $60,500,550,800$ and $900{ }^{\circ} \mathrm{C}$. Background XRD pattern is included for comparison.

To confirm the perovskite phase formation and to investigate if there is any secondary phase, present below the XRD detection limit $(\leq 2 \%)$, EDS analysis of the polished cross-section of LSM infiltrated Type "B"-cathodes was performed. As shown in Figure 4a, the elemental maps of manganese and lanthanum illustrate that both infiltrated elements are evenly distributed through the backbone layer, but the distribution it is not homogeneous following heating at $850{ }^{\circ} \mathrm{C}$ for $1 \mathrm{~h}$ as there are a few areas where those elements are not detected. Those areas correspond to those where the presence of strontium based phases was confirmed in Figure $4 \mathrm{~b}$, indicating that the perovskite phase obtained during firing at $850{ }^{\circ} \mathrm{C}$ is not pure. For this reason, the infiltrated cathodes with the LSM precursor solution were heated at $900{ }^{\circ} \mathrm{C}$ for $1 \mathrm{~h}$. The elemental maps of manganese, lanthanum, and strontium are homogeneously distributed, which indicates perovskite phase formation. Only a few spots, related to Mn-rich perovskite phases, are observed near the YSZ interface, as shown in Figure 4c. This fact is in agreement with Kim et al. [22] reporting that at $\geq$ 
$850{ }^{\circ} \mathrm{C}$ and under oxidizing conditions LSM nanoparticles deposited on YSZ single crystals might decompose into Mn- and La- rich phases.

In accordance with these results, firing at $900{ }^{\circ} \mathrm{C}$ for $1 \mathrm{~h}$ was chosen as the most suitable conditions to achieve the desire cathodes as it is more beneficial to achieve the perovskite phase with occasional Mn-rich phases than to obtain segregated phases based on strontium compounds and perovskite phases (by firing at $850{ }^{\circ} \mathrm{C}$ ).

It must be noted that the observation of $\mathrm{Ni}$ isolated grains in Type "B"-cathodes (Figure 4c) is because of the manufacturing process of the cells. Such cathode supports are obtained by acid etching of Ni-based microstructures and probably a few percent of the nickel is not completely removed as it is retained as the $\mathrm{NiO}$ phase.
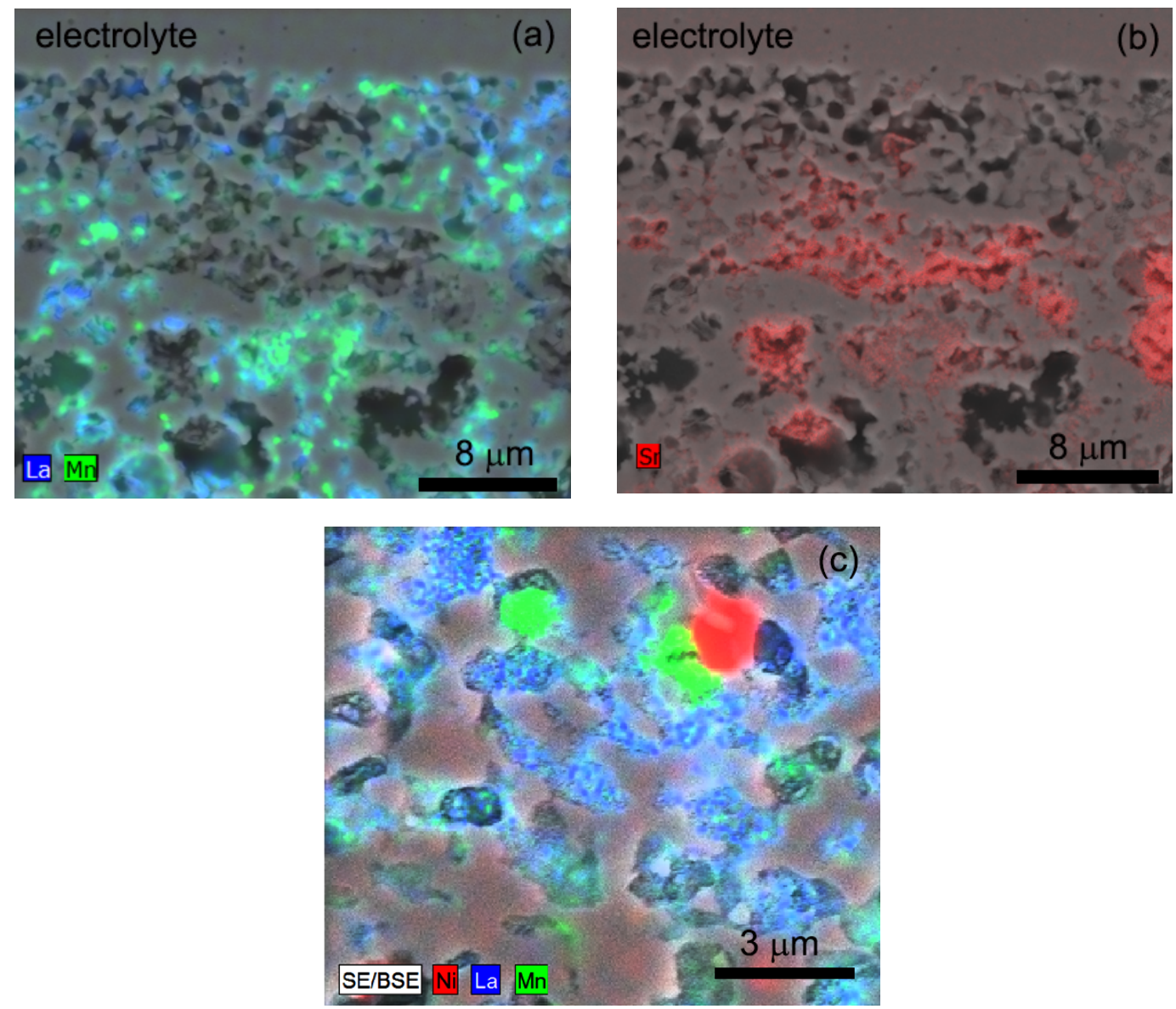

Figure 4. EDS maps of La, Sr, Mn, and Ni elements of polished cross-sections of Type "B" cathode infiltrated with LSM solution after heating at $(\mathrm{a}, \mathrm{b}) 850{ }^{\circ} \mathrm{C}$ or $(\mathrm{c}) 900{ }^{\circ} \mathrm{C}$.

SEM images of fractured samples after LSM infiltration are shown in Figure 5. The micrographs comprise the two types of cathode-supported half-cells pursued, Type "A"-cathode (LSM-YSZ 
support, YSZ backbone and YSZ electrolyte, Figures 5a and b) and Type "B"-cathode (thick YSZ backbone obtained by leaching and YSZ electrolyte, Figures 5c and d).

Type "A"-cathode, less porous than Type "B"-cathode (compared in Figures $5 \mathrm{~b}$ and d), are based on a multilayer structure consisting of $200 \mu \mathrm{m}$ thick LSM-YSZ support and $15 \mu \mathrm{m}$ thick YSZ backbone, layers which are LSM infiltrated. The infiltrated thin YSZ backbone will act as the functional cathode (Figure 5a). As the LSM is infiltrated into this interlayer, any reaction at high temperature between LSM and YSZ is avoided. This would not be the case for the LSM-YSZ support (Figure 5b), as the LSM is present as a composite component and, additionally, infiltrated afterwards. Although it is confirmed by XRD (Figure 3a) that the support consist of LSM and YSZ grains only, if there were any secondary phases present below the XRD detection limit $(\leq 2 \%)$, any such insulating phases would be present in as a very small fraction, and only in the support, not in the functional cathode (interlayer).
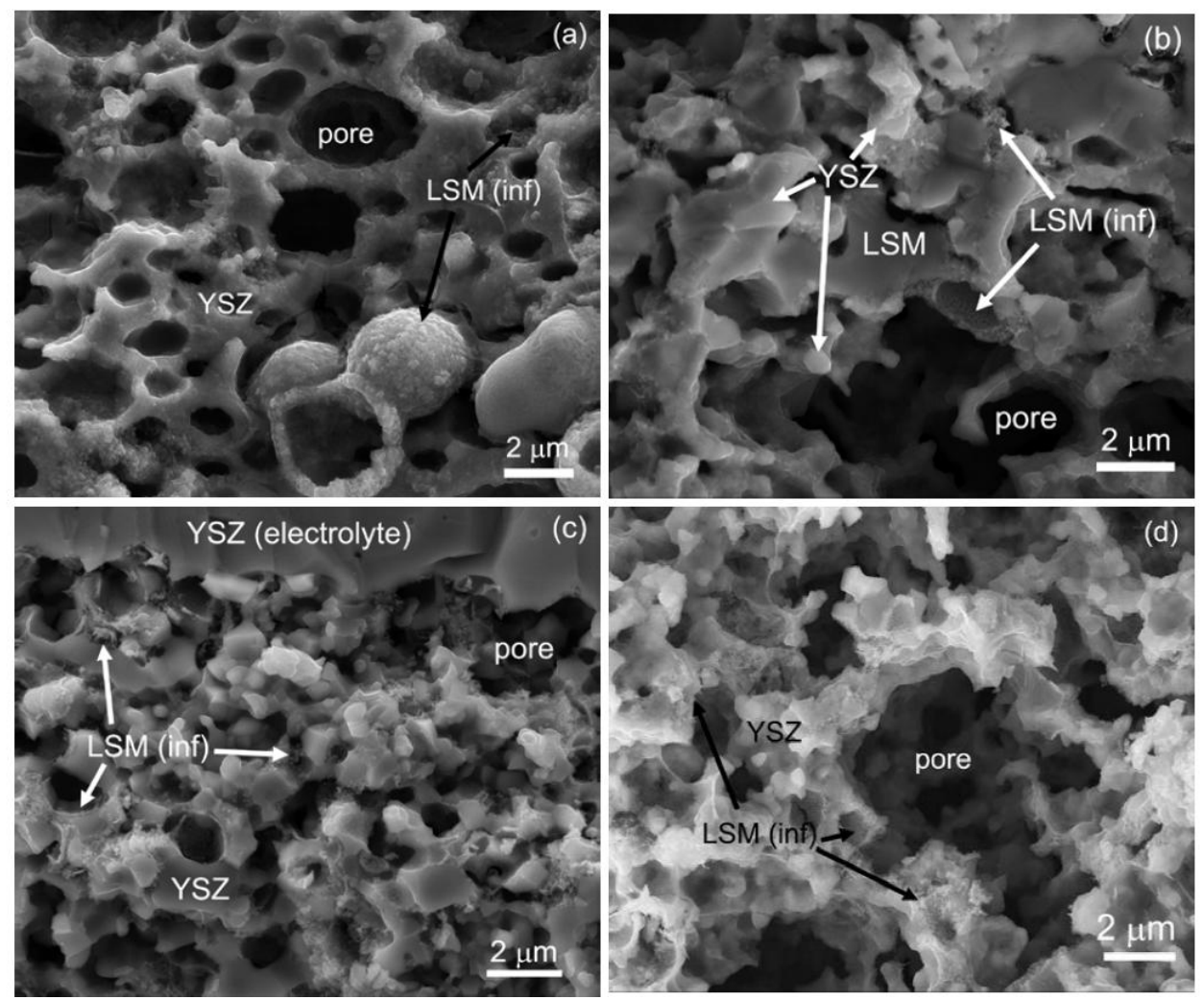

Figure 5. Microstructural details (fractured cross section) corresponding to LSM infiltrated (inf) half-cells: (a, b) Type "A," and (c, d) Type "B" cells. (a) YSZ interlayer backbone, (b) LSM-YSZ support, (c) YSZ backbone support in proximity to electrolyte, and (d) YSZ backbone support in central support area. 
The YSZ interlayer consist of a YSZ network with spherical pores around 1-2 $\mu \mathrm{m}$ in size whereas the backbone/support is formed by LSM grains, YSZ grains, and pores $\geq 2 \mu \mathrm{m}$, as seen in Figures $5 \mathrm{a}$ and $\mathrm{b}$, respectively. Upon infiltration, LSM nanoparticles coat the walls of the pores in both layers, forming a fairly densely packed coating of LSM all the way through the backbones/support.

The Type "B" cathode is based on a $315 \mu \mathrm{m}$ thick YSZ backbone, where the $15 \mu \mathrm{m}$ closer to the electrolyte (Figure 5c) present a finer porosity than the remaining $300 \mu \mathrm{m}$ (Figure $5 \mathrm{~d}$ ) such as to increase the triple phase boundaries. Upon infiltration, the vol.\% of LSM coating of the backbone is seen to increase as compared to Type "A" cathodes. In general, both types of structures would be suitable as cathodes, where LSM percolation through the entire cathode seems to be achieved, being more evident in backbones where the porosity is obtained by leaching (Type " $\mathrm{B}$ ").

\subsection{Electrochemical impedance studies}

Result of the electrochemical characterization can be found in Figure 6. It can be seen that there is a marked difference in the overall resistance of the symmetrical and quasi-symmetrical cells, depending on the backbone cathode architecture used. The lowest polarization resistance, $R_{p}$, is found for the symmetrical cell, showing that all the infiltrated backbones have a higher polarization resistance than the screen-printed cathodes (Figure 6a). The highest $R_{p}$ is found for the cells with the porous YSZ backbone support made by nickel etching (Type "B"-cathode). However, the difference between the Type "B" and the Type "A" (cathode with a LSM/YSZ support and YSZ backbone interlayer) is quite large, as shown in Figure 7. The series resistance, $R_{s}$, is lowest for the symmetrical cell, even though these have a much thicker electrolyte than the quasi-symmetrical cells (Figure 6b).
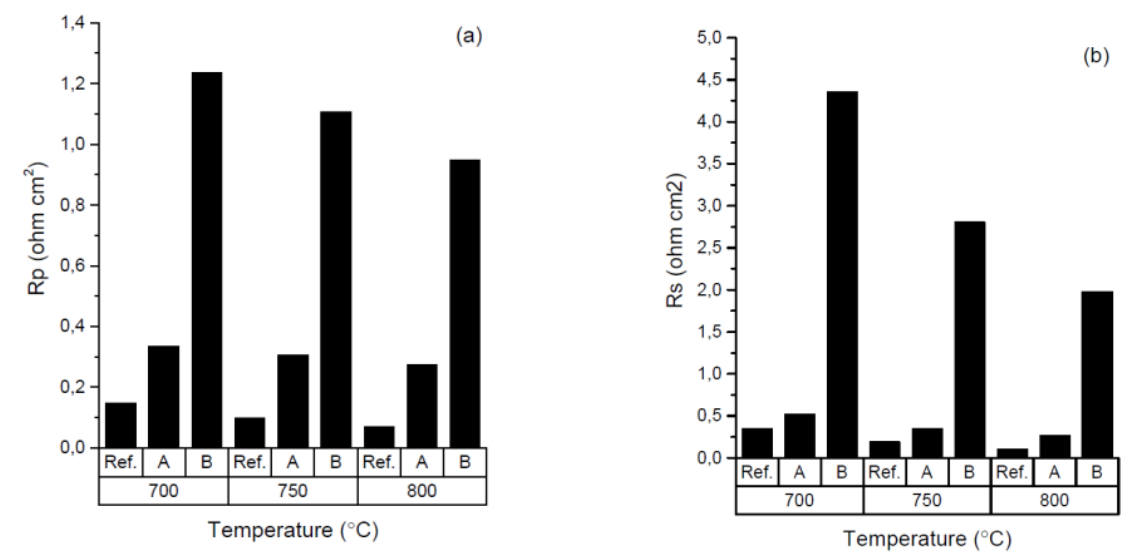

Figure 6. (a) $R_{p}$ and (b) $R_{s}$ as a function of temperature for the symmetrical reference (Ref.), and quasi-symmetrical cells with: Type "A" and Type "B" cathodes. 


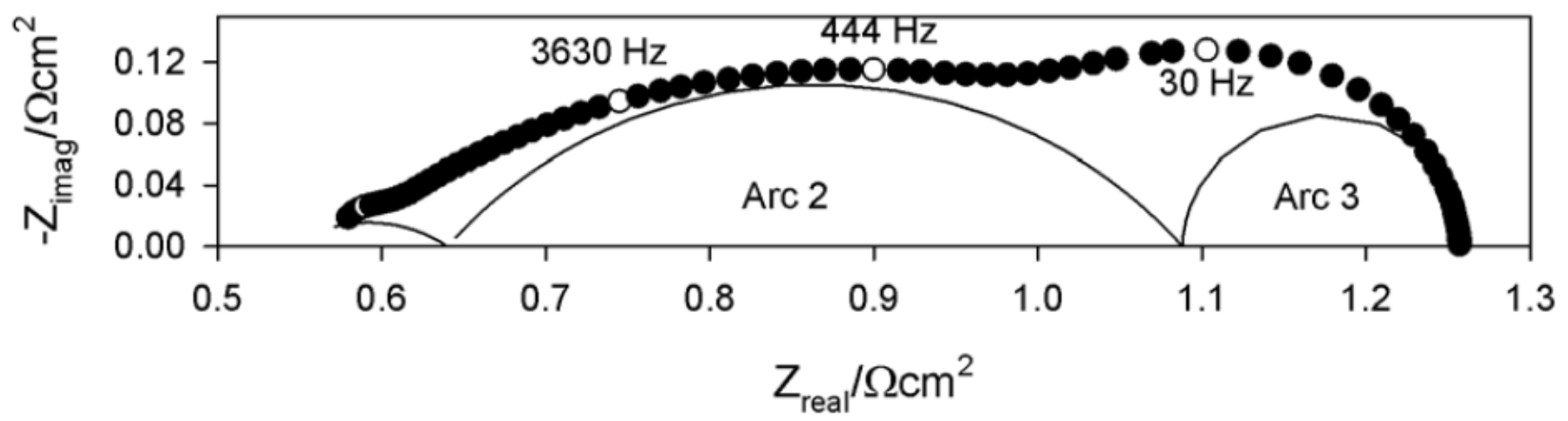

Figure 7. An example of an EIS spectrum recorded at $700{ }^{\circ} \mathrm{C}$ in $20 \% \mathrm{O}_{2}$ in $\mathrm{Ar}$ for the Type "A" sample.

A detailed EIS study reveals three arcs, as shown in Figure 7 and in Table 1-3. The arcs can be attributed to four processes as described in the literature $\left(\mathrm{R}_{\mathrm{s}}+4 \operatorname{arcs}\right)$ [23]. The high frequency arc is most likely due to transport of oxide ions between the electrode and the electrolyte, process A. this arc it is not possible to separate for the symmetrical sample from arc 2 for the highest temperature. The medium frequency arc is probably due to transport of oxide anions between LSM and YSZ, and through the YSZ in the composite. This process is only well separated for the Type " $\mathrm{B}$ " sample. The activation of this arc is $1 \mathrm{eV}$ for the Type " $\mathrm{B}$ " sample as also shown in the literature [23]. The third arc differs from the three types of electrodes. The third arc can be attributed to competitive elementary processes in the overall oxygen reaction mechanism. This arc is probably integrated in $R_{3}$ for the symmetrical cells and in $R_{2}$ for the Type " $A$ " sample. The low frequency arc ( $\mathrm{R}_{3}$ for the symmetrical cells and Type "A") is probably due to gas diffusion in a stagnant gas layer above the electrode.

The electrochemical characterization studies suggest Type "A" cathodes have moderate performance, which is still lower than that of the reference sample. This suggests the LSM infiltration process for the YSZ backbone interlayer is still poor, and the percolation of this layer is insufficient. In addition the long electronic path and diffusion of oxygen for this type of cell might explain the poorer performance. It should also be taken into account that the screen-printed reference cathode is sintered at a lower temperature $\left(1050{ }^{\circ} \mathrm{C}\right)$ than the developed Type " $\mathrm{A}$ " cathode. For Type "A", the infiltrated LSM was fired at $900{ }^{\circ} \mathrm{C}$, however during the fabrication of the cathode, the sample was sintered at $1250{ }^{\circ} \mathrm{C}$. Even though there is an interlayer of porous YSZ without LSM, the support layer consist of LSM/ YSZ composite which means that secondary solidstate reactions between LSM and YSZ from the support might not be fully avoided decreasing the performance of the resulting materials. 
Table 1-3. Activation energies and ASR values for the individual arcs.

\begin{tabular}{|l|l|l|l|l|}
\hline Ref. & Ea $(\mathrm{eV})$ & $700{ }^{\circ} \mathrm{C}\left(\Omega \mathrm{cm}^{2}\right)$ & $750{ }^{\circ} \mathrm{C}\left(\Omega \mathrm{cm}^{2}\right)$ & $800{ }^{\circ} \mathrm{C}\left(\Omega \mathrm{cm}^{2}\right)$ \\
\cline { 1 - 3 } $\mathrm{R}_{1}$ & 0.87 & 0.05 & 0.04 & 0.05 \\
\cline { 3 - 4 } $\mathrm{R}_{2}$ & & 0.09 & 0.03 & \\
\cline { 3 - 4 } $\mathrm{R}_{3}$ & 0.94 & 0.22 & 0.11 & 0.06 \\
\hline
\end{tabular}

\begin{tabular}{|l|l|l|l|l|}
\hline Type “A” & Ea $(\mathrm{eV})$ & $700{ }^{\circ} \mathrm{C}\left(\Omega \mathrm{cm}^{2}\right)$ & $750{ }^{\circ} \mathrm{C}\left(\Omega \mathrm{cm}^{2}\right)$ & $800{ }^{\circ} \mathrm{C}\left(\Omega \mathrm{cm}^{2}\right)$ \\
\hline $\mathrm{R}_{1}$ & 0.7 & 0.26 & 0.17 & 0.12 \\
\hline $\mathrm{R}_{2}$ & 1.23 & 0.47 & 0.23 & 0.12 \\
\hline $\mathrm{R}_{3}$ & 0 & 0.14 & 0.14 & 0.13 \\
\hline
\end{tabular}

\begin{tabular}{|l|l|l|l|l|}
\hline Type “B” & Ea $(\mathrm{eV})$ & $700{ }^{\circ} \mathrm{C}\left(\Omega \mathrm{cm}^{2}\right)$ & $750{ }^{\circ} \mathrm{C}\left(\Omega \mathrm{cm}^{2}\right)$ & $800{ }^{\circ} \mathrm{C}\left(\Omega \mathrm{cm}^{2}\right)$ \\
\hline $\mathrm{R}_{1}$ & 0.77 & 0.90 & 0.58 & 0.38 \\
\hline $\mathrm{R}_{2}$ & 1.01 & 1.51 & 0.80 & 0.50 \\
\hline $\mathrm{R}_{3}$ & 1.28 & 1.44 & 0.68 & 0.35 \\
\hline
\end{tabular}

Although developed infiltrated cathodes based on Type "A" demonstrate moderate performance when tested in quasi-symmetrical half cells, the concept allows the manufacture of cathode supported cells which otherwise might not be possible. As shown in Figure 8 the performance for Type "A" cathode-supported cell increases from 44 to $75 \mathrm{~mW} / \mathrm{cm}^{2}$, i.e. $70 \%$ of improvement when compared to the anode-supported cell.

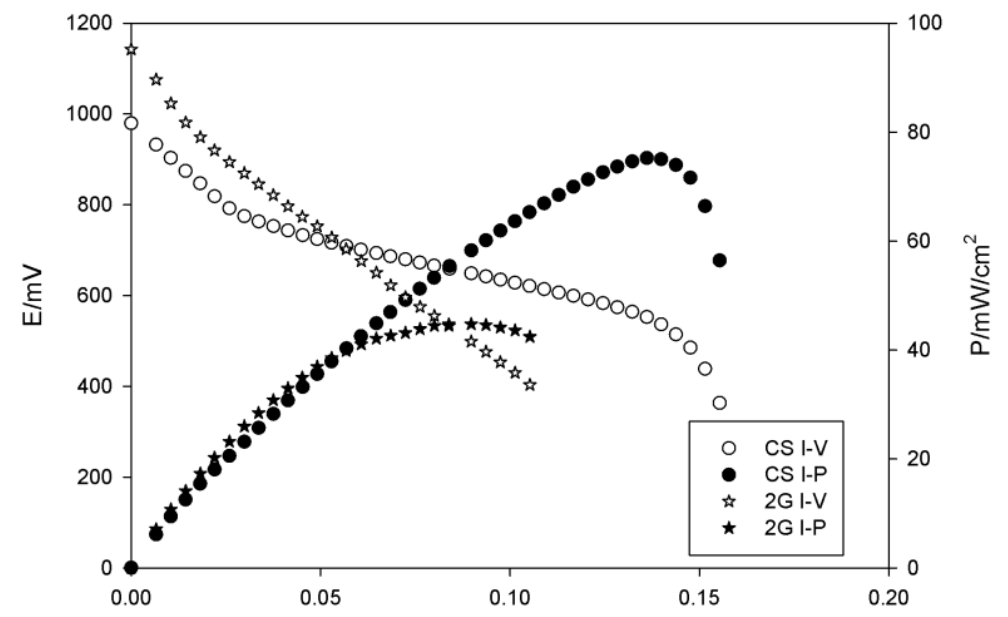

Figure 8. Polarization curves of the HDGEG $\mathrm{ns}^{2}$ based on anode-supported cells (2G) and Type "A" cathode-supported cells (CS) measured at $755^{\circ} \mathrm{C}$ with air at the cathode and 4:1 wt.\% carbon black acetylene:( $\mathrm{Li}-\mathrm{K})_{2} \mathrm{CO}_{3}$ under $20: 80$ vol\% $\mathrm{CO}_{2}: \mathrm{N}_{2}$ at the anode. 


\section{Conclusions}

This study demonstrates the potential of an alternative configuration for planar HDCFCs improving the performance in a factor of 1.7 when compared to anode-supported cells. The feasibility of the use of infiltrated porous backbones as functional cathodes or support layers for the development of cathode-supported cells is investigated..

The infiltrated cathodes show, in the best case, a performance similar to a screen-printed composite cathode, when tested in a (quasi-)symmetrical half-cell configuration. These results confirm the viability of the use of the interlayer infiltrated backbone as the functional cathode, ensuring both the absence of undesirable secondary reaction while he electrolyte density is ensured, two key points that are not achieved with the state-of-the-art cathodes based on LSM/YSZ composites.

\section{Acknowledgements}

This work was supported financially by the Department of Energy Conversion and Storage, Technical University of Denmark. Part of this work was further supported by the European Commission Research Fund for Coal and Steel, as the Efficient Conversion of Coal to ElectricityDirect Coal Fuel Cells project. The authors thank the technical staff at the DTU Department of Energy Conversion and Storage for technical support in sample fabrication. We extend our thanks to Topsoe Fuel Cell A/S for the anode-supported fuel cells.

\section{References}

[1] Gür TM. Critical review of carbon conversion in carbon fuel cells. Chem Rev 2013;113:6179206.

[2] Chien AC, Irvine JTS. Hybrid Molten Carbonate/Solid Oxide Direct Carbon Fuel Cells. Molten Salts Chemistry: From Lab to Applications. Elsevier; 2013, p. 403-12.

[3] Chien AC, Arenillas A, Jiang C, Irvine JTS. Performance of Direct Carbon Fuel Cells Operated on Coal and Effect of Operation Mode. J Electrochem Soc 2014;161:F588-93.

[4] Xu X, Zhou W, Liang F, Zhu Z. A comparative study of different carbon fuels in an electrolytesupported hybrid direct carbon fuel cell. Appl Energy 2013;108:402-9.

[5] Cantero-Tubilla B, Xu C, Zondlo JW, Sabolsky K, Sabolsky EM. Investigation of anode configurations and fuel mixtures on the performance of direct carbon fuel cells (DCFCs). J Power Sources 2013;238:227-35.

[6] Jiang C, Ma J, Arenillas A, Bonaccorso AD, Irvine JTS. Comparative study of durability of hybrid direct carbon fuel cells with anthracite coal and bituminous coal. Int. J. Hydrogen Energy 2016;41:18797-06.

[7] Deleebeeck L, Hansen KK. Hybrid direct carbon fuel cells and their reaction mechanisms-a review. J Solid State Electrochem 2013;18:861-82.

[8] Deleebeeck L, Ippolito D, Hansen KK. Catalytic Enhancement of Carbon Black and CoalFueled Hybrid Direct Carbon Fuel Cells. J Electrochem Soc 2015;162:F327-39. 
[9] Huang K and Singhal SC, Cathode-supported tubular solid oxide fuel cell technology: a critical review, J. Power Sources 2013;237:84-97.

[10] Chen M, Luo JL, chuang KT, Sanger AR. Fabrication and electrochemical properties of cathodesupported solid oxide fuel cells via slurry spin coating, Electrochim. Acta 2012;63:277-86.

[11] Rehman S, Song RH, Lee JW, Lim TH, Park SJ, Lee SB. Effect of GDC addition method on the properties of LSM-YSZ composite cathode support for solid oxide fuel cells. Ceramics 2016;42:11772-9.

[12] Rehman S, Song RH, Lee JW, Lim TH, Park SJ, Lee SB. Fabrication and characterization of $\left.\mathrm{La}_{0.65} \mathrm{Sr}_{0.3} \mathrm{MnO}_{3-\delta} / \mathrm{Y}_{2} \mathrm{O}_{3}\right)_{0.08}\left(\mathrm{ZrO}_{2}\right)_{0.92} / \mathrm{Gd}_{0.1} \mathrm{Ce}_{0.9} \mathrm{O}_{2-\delta}$ tri-composite cathode-supported tubular direct carbon solid oxide fuel cell. Ceramics International 2016;doi:10.1016/j.ceramint.2016.10.045.

[13] Vohs JM, Gorte RJ. High-Performance SOFC Cathodes Prepared by Infiltration. Adv Mater 2009;21:943-56.

[14] Adijanto L, Küngas R, Bidrawn F, Gorte RJ, Vohs JM. Stability and performance of infiltrated $\mathrm{La}_{0.8} \mathrm{Sr}_{0.2} \mathrm{Co}_{\mathrm{x}} \mathrm{Fe}_{1-\mathrm{x}} \mathrm{O}_{3}$ electrodes with and without $\mathrm{Sm}_{0.2} \mathrm{Ce}_{0.8} \mathrm{O}_{1.9}$ interlayers. $\mathrm{J}$ Power Sources 2011;196:5797-802.

[15] Park S, Gorte RJ, Vohs JM. Tape Cast Solid-Oxide Fuel Cells for the Direct Oxidation of Hydrocarbons. J Electrochem Soc 2001;148:A443-7.

[16] Larsen PH, Brodersen K. Method for the manufacture of reversible solid oxide cells. US2008124602-A1; 2008.

[17] Gil V, Hansen KK. High Performance Infiltrated Backbones for Cathode-Supported SOFCs. ECS Trans 2014;64:41-51.

[18] Gil V, Larrea A, Merino RI, Orera VM. Redox behaviour of Gd-doped ceria-nickel oxide composites. J Power Sources 2009;192:180-4.

[19] Carman PC. Flow of Gases Through Porous Media. Academic Press;1956.

[20] Corbin SF, Apté PS. Engineered Porosity via Tape Casting, Lamination and the Percolation of Pyrolyzable Particulates. J Am Ceram Soc 1999;82:1693-01.

[21] Altena FWW, Knoef H, Heskamp H, Bargeman D, C.A.A. Smolders, Some comments on the applicability of gas permeation methods to characterize porous membranes based on improved experimental accuracy and data handling, J Memb Sci 1983;12:313-22.

[22] Kim JS, Lee S, Gorte RJ, Vohs JM. Substrate-mediated spreading and phase segregation at LSM-Zirconia interfaces, J. Electrochemical Society 2010;158(2):B79-83.

[23] Jørgensen MJ and Mogensen M. Impedance of solid oxide fuel cell LSM/YSZ composite cathodes. J Electrochem Soc 2001;148(5):A433. 